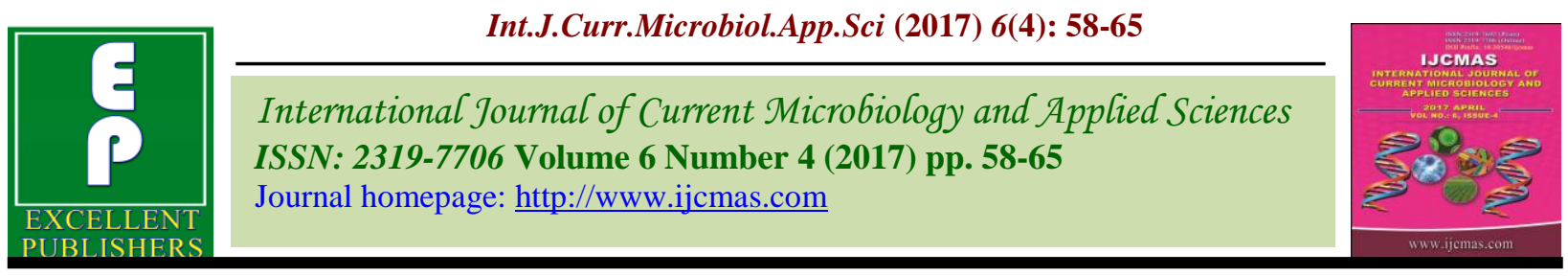

Original Research Article

https://doi.org/10.20546/ijcmas.2017.604.008

\title{
Dissemination and Utilization of Market Information System by Farmers for Gram Crop in Bhiwani District of Haryana, India
}

\author{
Veer Sain*, K.K. Kundu and V.P. Mehta \\ Department of Agricultural Economics, Choudhary Charan Singh Haryana Agricultural \\ University, Hisar -123005, India \\ *Corresponding author
}

\begin{abstract}
A B S T R A C T
Keywords

Marketing

Information System,

Regulated market,

Farmers, Bhiwani.

Article Info

Accepted:

02 March 2017

Available Online:

10 April 2017

Gram is a suitable crop in Bhiwani district of Haryana covering Siwani and Tosham Blocks were selected purposively on the basis of maximum production under gram crop. Further, Bhiwani, Dadri, Siwani and Tosham markets were selected for the market study. Finally, 60 farmers were randomly selected from these two blocks of Bhiwani district were randomly selected. From the findings of the research study in Bhiwani district farmers, awareness on prices and arrivals in other market were of I-Rank and II-Rank and awareness on price in reference and arrival in reference market was III-Rank and IV-Rank. Contacts in other markets and fellow traders formed major sources of market information in Bhiwani district. The daily prices were compiled manually and written on the notices board for the use of the farmers visiting the market. The information is disseminated through various media like neighbors, newspapers, relatives etc. About $85.0 \%$ of farmers expressed that market information was not available in required form in Bhiwani district. Farmers have also faced difficulty on accessibility aspects (73.3\%).
\end{abstract}

\section{Introduction}

Marketing Information Systems as an interacting structure of people, equipments and procedures to gather sort, analyze, evaluate and distribute, timely and accurate information for use by marketing decision makers to improve their marketing planning, implementation, and control. Marketing Information System has four parts, which are Internal Records, Marketing Intelligence, Marketing Research, and Marketing Decision Support System (MDSS). Internal records are the most used information in all the companies around the world such as reports of orders, sales, prices, costs, inventory levels, receivables, payables and so on. Market intelligence system is a set of procedures and sources used by managers to obtain their everyday information about pertinent developments in the marketing environment (Kotler and Armstrong, 2010). In addition study indicated that the illiteracy levels of farmers coupled with limited access or no access to electronic devices, led to unawareness of modern electronic devices which are more accurate and with in less time help in marketing process than traditional means of methods/measurements. The use of electronics devices in the markets could only reduce the marketing. The electronic balance/scale, electronic display and use of 
computers for tendering were the only few electronic devices used in the regulated markets. Further, selling operation time had reduced considerably in these markets due to the use of e-balance and the e-tendering process. The study also points out that the payments to the farmers were made between 1 and 15 days in all the markets. Thus, these electronic equipments had no direct impact on the price mechanism but alleviated the buying and selling processes. Hence, the study suggests that there is an immediate need to introduce/put to use the electronic display boards, TV display in these markets for the benefit of farmers (Amrutha et al., 2015).

Pulses include a number of crops which are mostly leguminous and provide much needed vegetable proteins to a largely vegetarian population of India. They serve as excellent forage and grain concentrates in the feed of cattle. Pulses have the capacity to fix atmospheric nitrogen in the soil and are normally rotated with other crops to maintain or restore soil fertility. Though gram and tur (arhar) are the more important pulses, several other pulses such as urd (blackgram), mung (greengram), masur (lentil), kulthi (horsegram), matar (peas), khesri and moth are also grown. It can be grown in a wide range of climatic conditions but it prefers mild cool and comparatively dry climate with $20^{\circ}-25^{\circ} \mathrm{C}$ temperature and $40-50 \mathrm{~cm}$ rainfall. It is cultivated as pure or mixed with wheat, barley, linseed or mustard. In Haryana, Hisar, Sirsa, Rohtak, Mahendergarh, Gurgaon, Jind, Kaithal and Karnal districts are the main producers.

The bulk of gram in Maharashtra comes from Usmanabad, Ahmednagar, Aurangabad, Nashik, Solapur, Parbham and Beed districts and small quantity is also produced in Bihar, Gujarat, Karnataka Andhra Pradesh and Punjab. Gram was grown, currently, in an area of 55 thousand ha, with production of 42 thousand tonnes and productivity of 646 $\mathrm{kg} /$ ha during 2014-15.

The specific objectives of this study are to study the existing market information system for Gram crop of Bhiwani in Haryana and also to study the pattern and extent of dissemination and utilization of existing formal information by stakeholders, and to identify the constraints in the existing formal information system and suggest alternatives.

\section{Materials and Methods}

The present study has been carried out on the basis of primary sources were collected by personnel interview method by using pretested structured schedule prepared for the purpose. Bhiwani district was purposively selected due to maximum production under Gram. In Bhiwani district two blocks (Siwani and Tosham) were selected due to the maximum area. From Bhiwani district four regulated markets were selected due to maximum arrivals of Bhiwani. From two blocks four villages (MIS Adopters and NonAdopters) was randomly selected. Interview method was developed to get complete and reliable information with the help of wellstructured schedule. To study the sources of agriculture market information and their utilization among the 60 farmers from village were selected for the study based on random sampling technique. To understand the market information system for agricultural commodities, farmers, tabular analysis with simple averages, percentages etc. were computed.

The find out nature, extent, sources and utilization of the market information system by farmers, tabular analysis with simple averages, percentages etc. were computed. The farmers response was scored giving a weight of 3 for 'always', 2 for 'sometime', 1 for 'rarely' and 1 for 'yes' and 0 for 'No'. 
Farmers awareness on agricultural market information system in Bhiwani district of Haryana

\section{Awareness of farmers}

Table 1 indicated the awareness of the sample farmers on different components of market information. In Bhiwani district of farmers, the awareness on prices in other markets was found to be I-Rank and awareness on arrivals in other markets was II-Rank MIS Adopters in Bhiwani district of markets. However, arrivals in reference market were III-Rank and prices in reference market were IV Rank. It is interesting to note that Bhiwani district of Gram farmers was aware of either area, production, quality of produce to particular crops. It is worth noting but similar pattern follows, Bhiwani district of farmers were aware of parameters like area sown V Rank and quality/grade of produce VI-Rank. Similar findings were also reported by Hatai and Panda (2015).

\section{Sources of market information of farmers}

Table 2 showed that the sources of market information at village level on arrival information indicated that Neighbors and newspapers (I Rank) and (II Rank) were the general sources of market information of Bhiwani district of village farmers. Whereas Relatives and Television (III Rank) and (IV Rank) in Bhiwani district of villages formed the sources of market information. Neighbor's formed the major source of market information in Bhiwani district of Villages. The institutional agencies like Gram Panchayat, co-operative credit society and SHG's did provide labor's market information. However, Krishi Vigyan Kendra's (KVKs) were part of market information to farmers at village level. Commission agents are the most sought after market information sources (70.0\%), Announcement by APMC (63.3\%), Display
board/Ticker board $(50.0 \%)$ in Bhiwani district of villages at the market level (Table 3). Similar findings were also reported by Amrutha and Hugar (2009).

\section{Pattern of dissemination of market information}

\section{Mode and frequency of dissemination}

The markets resorted to different modes of dissemination of the market information in all the four markets of Bhiwani district. The market information was transmitted through notice boards, announcements in market yards, fax, phone, AIR, television and newspapers (Table 4).

The market information was disseminated daily to the District Information Officer, AIR, newspaper, television, internet and District Statistical Officer. Whereas, it was transmitted to Haryana State Agriculture Marketing Board (HSAMB) on the weekly, monthly and annual basis, similarly, the market information was also sent to Gram/Zilla Panchayat, Agriculture Research Station and Deputy Commissioner once in a year in the form of annual reports (Table 5). Similar findings were also reported by Amrutha and Hugar (2009).

\section{Utilization by farmers}

The table 6 indicated the extent of market information utilized by Bhiwani district of farmers in decision making. It can be clearly seen that making use of market information on arrivals in decision making on various aspects of farming. However, about $93.3 \%$ used the information in deciding the crops to be sown. In case of post harvest technique majority was drying (96.7\%) in Bhiwani district of farmers. Another case in selling decision majority was when to sell $(90.0 \%)$ in Bhiwani district of farmers. 
Table.1 Farmers awareness on regulated market information for gram in Bhiwani district of Haryana

$\mathbf{n}=60$

\begin{tabular}{|c|c|c|c|c|c|c|c|c|c|}
\hline \multirow{4}{*}{$\begin{array}{c}\text { S. } \\
\text { No. }\end{array}$} & \multirow{4}{*}{ Type of market information } & & & & & & & & \\
\hline & & \multicolumn{8}{|c|}{ Degree of Awareness } \\
\hline & & \multicolumn{2}{|c|}{ Always } & \multicolumn{2}{|c|}{ Sometime } & \multicolumn{2}{|c|}{ Rarely } & \multirow{2}{*}{$\begin{array}{l}\text { Total } \\
\text { score }\end{array}$} & \multirow{2}{*}{$\begin{array}{c}\text { Ran } \\
\mathbf{k}\end{array}$} \\
\hline & & Response & Score & Response & Score & Response & Score & & \\
\hline 1 & Arrivals in other market (Bhiwani and Dadri) & $33(55.0)$ & 99 & $26(43.3)$ & 52 & $1(1.7)$ & 1 & 152 & II \\
\hline 2 & Arrivals in reference market (Tosham and Siwani) & $28(46.7)$ & 84 & $32(53.3)$ & 64 & $0(0.0)$ & 0 & 148 & III \\
\hline 3 & Prices in other market (Bhiwani and Dadri) & $37(61.7)$ & 111 & $20(33.3)$ & 40 & $3(5.0)$ & 3 & 154 & $\mathrm{I}$ \\
\hline 4 & Prices in reference market (Tosham and Siwani) & $27(45.0)$ & 81 & $33(55.0)$ & 66 & $0(0.0)$ & 0 & 147 & IV \\
\hline 5 & Area under crops & $21(35.0)$ & 63 & $28(46.7)$ & 56 & $11(18.3)$ & 11 & 130 & $\mathrm{~V}$ \\
\hline 6 & Grade/Standard required & $0(0.0)$ & 0 & $0(0.0)$ & 0 & $0(0.0)$ & 0 & 0.0 & VI \\
\hline
\end{tabular}

Figure in the parentheses indicate percentage to total

Table.2 Farmers sources of market information at village level in Bhiwani district of Haryana

$\mathrm{n}=60$

\begin{tabular}{|c|c|c|c|c|c|c|c|c|c|}
\hline \multirow[t]{3}{*}{ S. No. } & \multirow[t]{3}{*}{ Sources } & \multicolumn{8}{|c|}{ Degree of Awareness } \\
\hline & & \multicolumn{2}{|c|}{ Always } & \multicolumn{2}{|c|}{ Sometime } & \multicolumn{2}{|c|}{ Rarely } & \multirow[t]{2}{*}{ Total score } & \multirow[t]{2}{*}{ Rank } \\
\hline & & Response & Score & Response & Score & Response & Score & & \\
\hline 1 & Newspaper & $31(51.7)$ & 93 & $27(45.0)$ & 54 & $2(3.3)$ & 2 & 149 & II \\
\hline 2 & Television & $24(40.0)$ & 72 & $23(38.3)$ & 46 & $13(21.7)$ & 13 & 131 & IV \\
\hline 3 & Radio & $21(35.0)$ & 63 & $19(31.7)$ & 38 & $20(33.3)$ & 20 & 121 & $\mathrm{~V}$ \\
\hline 4 & Gram Panchayat & $3(5.0)$ & 9 & $9(15.0)$ & 18 & $48(80.0)$ & 48 & 60 & $\mathrm{XI}$ \\
\hline 5 & Neighbors & $32(53.3)$ & 96 & $28(46.7)$ & 56 & $0(00.0)$ & 0 & 152 & $\mathrm{I}$ \\
\hline 6 & Relatives & $29(48.3)$ & 87 & $23(38.3)$ & 46 & $8(13.3)$ & 8 & 141 & III \\
\hline 7 & Cooperative credit society & $19(31.7)$ & 57 & $20(33.3)$ & 40 & $21(35.0)$ & 21 & 118 & $\mathrm{VI}$ \\
\hline 8 & SHGS & $13(21.7)$ & 39 & $15(25.0)$ & 30 & $32(53.3)$ & 32 & 101 & VII \\
\hline 9 & KVKs & $16(26.7)$ & 48 & $18(30.0)$ & 36 & $26(43.3)$ & 26 & 110 & $\mathrm{~V}$ \\
\hline 10 & Magazine & $10(16.7)$ & 30 & $18(30.0)$ & 36 & $32(53.3)$ & 32 & 98 & VIII \\
\hline 11 & Internet & $11(18.3)$ & 33 & $12(20.0)$ & 24 & $37(61.7)$ & 37 & 94 & IX \\
\hline
\end{tabular}


Table.3 Farmers sources of market information at market level in Bhiwani district of Haryana $\mathbf{n}=60$

\begin{tabular}{|l|l|c|c|}
\hline S. No. & Source of market information & No. & Percentage \\
\hline 1 & Commission Agents & 42 & 70.0 \\
\hline 2 & Announcement by APMC & 38 & 63.3 \\
\hline 3 & $\begin{array}{l}\text { Display boards/ } \\
\text { Ticker Boards }\end{array}$ & 30 & 50.0 \\
\hline 4 & Input dealer & 26 & 43.3 \\
\hline
\end{tabular}

Table.4 Dissemination of market information in Bhiwani district markets of Haryana

\begin{tabular}{|l|l|c|c|}
\hline $\begin{array}{l}\text { S. } \\
\text { No. }\end{array}$ & $\begin{array}{l}\text { Mode of } \\
\text { dissemination }\end{array}$ & Score & Percentage \\
\hline 1 & Notices board & 4 & 100.0 \\
\hline 2 & Announcement & 4 & 100.0 \\
\hline 3 & Fax & 4 & 100.0 \\
\hline 4 & Telephone & 4 & 100.0 \\
\hline 5 & Internet & 4 & 100.0 \\
\hline 6 & AIR & 4 & 100.0 \\
\hline 7 & Television & 4 & 100.0 \\
\hline 8 & Posts & 4 & 100.0 \\
\hline 9 & Newspaper & 4 & 100.0 \\
\hline
\end{tabular}

Table.5 Distribution of market information to different agencies in Bhiwani district markets of Haryana

$n=4$

\begin{tabular}{|l|l|c|c|}
\hline $\begin{array}{l}\text { S. } \\
\text { No. }\end{array}$ & Mode of dissemination & Score & Percentage \\
\hline 1 & $\begin{array}{l}\text { State Agricultural } \\
\text { Marketing Board }\end{array}$ & 4 & 100.0 \\
\hline 2 & $\begin{array}{l}\text { Department of } \\
\text { Agriculture }\end{array}$ & 4 & 100.0 \\
\hline 3 & District Statistical Offices & 4 & 100.0 \\
\hline 4 & Research Station & 4 & 100.0 \\
\hline 5 & Newspapers & 4 & 100.0 \\
\hline 6 & Gram Panchayat & 2 & 50.0 \\
\hline
\end{tabular}


Table.6 Extent of Market Information utilization by farmers in Bhiwani district of Haryana

\begin{tabular}{|l|l|c|c|}
\hline \multicolumn{3}{|c|}{ Arrival and Price in reference } \\
market & Nature/Types of decision & No. & $\begin{array}{c}\text { Percenta } \\
\text { ge }\end{array}$ \\
\hline S. No. & \multicolumn{3}{|c|}{} \\
\hline $\mathbf{1}$ & Production decisions & 56 & 93.3 \\
\hline I & Crops to be sown & 21 & 35.0 \\
\hline II & Area to be sown & 54 & 90.0 \\
\hline $\mathbf{2}$ & Selling decisions & 51 & 85.0 \\
\hline I & When to sell & 46 & 76.7 \\
\hline II & Where to sell & 40 & 66.7 \\
\hline III & Whom to sell & 58 & 96.7 \\
\hline IV & Quantity to sell & 42 & 70.0 \\
\hline $\mathbf{3}$ & Post harvest handling decisions & 48 & 80.0 \\
\hline I & Drying & & \\
\hline II & Bagging & Transportation & \\
\hline III & \multicolumn{3}{|l|}{} \\
\hline
\end{tabular}

Table.7 Benefits derived from market information by farmers in Bhiwani district of Haryana

\begin{tabular}{|l|l|c|c|}
\hline S. No. & Types of Benefits & No. & Percentage \\
\hline 1 & By changing place of sale & 38 & 63.3 \\
\hline 2 & Changing time of sale & 30 & 50.0 \\
\hline 3 & Drying of produce & 40 & 66.7 \\
\hline 4 & By storage & 26 & 43.3 \\
\hline 5 & By change of mode of transportation & 26 & 43.3 \\
\hline 6 & By better mode of packaging & 24 & 40.0 \\
\hline
\end{tabular}

Table.8 Constraints as perceived by farmers in existing Agriculture Marketing Information's of Bhiwani district of Haryana

$\mathbf{n}=60$

\begin{tabular}{|l|l|c|c|}
\hline $\begin{array}{l}\text { S. } \\
\text { No. }\end{array}$ & Constraints & No. & Percentage \\
\hline 1 & Accessibility & 44 & 73.3 \\
\hline 2 & Costly & 6 & 10.0 \\
\hline 3 & Non- availability in time & 30 & 50.0 \\
\hline 4 & $\begin{array}{l}\text { Non-availability of required information on price/ price in other } \\
\text { markets/ arrival/ area/ production }\end{array}$ & 34 & 56.7 \\
\hline 5 & Non-availability of information in required form & 51 & 85.0 \\
\hline 6 & Face to high transportation costs & 43 & 71.7 \\
\hline 7 & Better Marketing facilities and warehousing facilities & 26 & 43.3 \\
\hline
\end{tabular}


In case of where to sell $(85.0 \%)$ in Bhiwani district used the information on market arrivals, respectively. Similar findings were also reported by Hatai and Panda (2015).

\section{Benefits derived from market information by farmers}

Table 7, indicated that the benefits from Ambala district of farmers have derived as per their opinion by utilizing market information. It revealed that farmers were benefited and obtained higher price by utilizing the market information's system. In case of Ambala district of farmers, the market information was used in deciding to drying of producers (76.7\%), change of place of sale $(70.0 \%)$, change of time of sale $(60.0 \%)$ and by storage (46.7\%). Similar findings were also reported by Hatai and Panda (2015).

\section{Constraints, expectations and suggestions of stakeholder on market information's}

\section{Constraints faced by farmers}

The constraints as perceived by traders in the existing market information are presented in table 8 . About $(85.0 \%)$ of farmers expressed that market information was not available in required form in Bhiwani district. Farmers were also faced difficulty on accessibility aspects (73.3\%), followed by high transportation cost aspect $(71.7 \%)$, followed by non-availability of required information on price/prices in other markets/ production aspect $(56.7 \%)$, followed by better marketing facilities and warehousing facilities aspect (43.3\%), followed by Non-availability in time aspect $(50.0 \%)$ in Bhiwani district. Similar findings were also reported by Sankar and Singh (2014)

It is concluded based on following finding of the study for improving the agricultural marketing information system in Bhiwani district of Haryana, awareness of farmers on different components of market information was not very bad in Bhiwani district. None of the selected district farmers was aware of either area, production, quality of produce or scientific post harvest handling of the produce. Unlike farmers were aware of information on these aspects besides details of the produce in Bhiwani district markets.

Farmer's sources of market information at village level, neighbors and newspapers were the main source of market information to the farmers whereas, commission agents were the most sought source at the market level. Some of the Bhiwani district farmers also relied on magazines and internet as their sources of market information. Besides a very few farmers also depended on the announcements and display boards at the market. Contacts in other markets and fellow traders were the major source of the market information to the traders of selected district markets. The modes of dissemination of market information were the traditional announcements, display boards, transmission through television and newspapers of Bhiwani district markets.

The utility of market information was low among the farmers. The benefits derived in the form of higher price by farmers were significant of Bhiwani district markets. Non availability of real information on prices was the major constraint as opined by farmers. The markets were facing the constraint of inadequate personnel of Bhiwani district markets. The MIS should be deliver fast, reliable and accurate information in a user friendly manner for utilization by the farmers and other stakeholders in order to facilitate the farmers to decide what and when make crop and marketing planning, how to cultivate, when and how to harvest, what post harvest management practices to follow, when, where, how to sell etc. of the agricultural produce in the study area. 


\section{References}

Amrutha, C.F. and Hugar, L.B. 2007. An economic analysis of dissemination and utilization of market information on onion in Karnataka. Int. J. Commerce and Business Management, 2(2): 132135.

Amrutha, T.J., Siddayya and Reddy, S.V. 2015. A comparative study on use of electronic devices in agricultural marketing in Nek region. Indian J. Agri. Marketing, 29(1): 1-20.

Hatai, L.D. and Panda, D. 2015. Agricultural
Marketing Information System: A Case Study of Traders in Meghalaya. Economic Affairs, 60(2): 263-271.

Kotler, P. and Armstrong, G. 2010. Principle of Marketing, 13th edition, New Jersey, Prentice Hall International.

Kotler, P. and Keller, K. 2012. Marketing Management, 14th edition, Englewood Cliffs NJ, Prentice Hall International.

Sankar, M.S. and Singh, A. 2014. Agricultural Produce Market Committee (APMC) Act in Uttarakhand and its impact on agribusiness. Int. $J$. Marketing and Technol., 4(4): 189-203.

\section{How to cite this article:}

Veer Sain, K.K. Kundu and Mehta, V.P. 2017. Dissemination and utilization of Market Information System by farmers for Gram crop in Bhiwani district of Haryana, India. Int.J.Curr.Microbiol.App.Sci. 6(4): 58-65. doi: https://doi.org/10.20546/ijcmas.2017.604.008 